\title{
小学校理科生物分野における子どもの資質・能力の育成に関する一考察 一腹面から描いた「昆虫の体のつくり」の認識状態に基づいてー
}

\author{
佐々木智謙 ${ }^{1}$ \\ 佐藤 寛之 ${ }^{1}$ \\ 塚原 健将 ${ }^{2}$ \\ 松森 靖夫 $^{1}$
}

\begin{abstract}
【要約】
本研究の主目的は, 腹面から描いた昆虫の体のつくりに対する小学校第 $2 \cdot 3$ 学年の認識状 態を分析し，その結果に基づき，育成すべき子どもの資質・能力について検討を加えること にある。得られた知見は，以下の 4 点である。1）腹面から描いた計 9 種類の生き物を，昆虫 とその他の生き物とに分類できた小 2 は約 $60 \%$ 以上，小 3 は $80 \%$ 以上であったこと。2）腹 面から描いた計 6 種類全ての昆虫の体を三つの部分（頭部・胸部・腹部）に正しく分けるこ とができた小 2 は皆無であり，小 3 でも約 $20 \%$ であったこと。かつ, 各昆虫の正答率は小 2 で $10 \%$ 未満，小 3 でも $65 \%$ 未満であったこと。3）昆虫の体のつくりに対する回答は多様で あり, 頭部で 4 類型, 胸部で 9 類型, 及び腹部で 3 類型が存在したこと。4）得られた結果を もとに，昆虫概念の育成を志向した学習指導方策について提案した。
\end{abstract}

[キーワード］昆虫の体のつくり, 小学校理科, 科学的認識, 生物教育, 生物分野の資質・能力

\section{1. はじめに}

周知の通り, 新学習指導要領（文部科学省, 2017a； 文部科学省, 2017b）において,「生命」を柱とする 領域は,「生命」に関する自然の事物・現象を, 主に 多様性と共通性の視点で捉えるという見方や, 比較 したり関係づけたりするなどの考え方等を働かせて， 子ども達に生物分野の資質・能力を育成するという 新たな文脈のもとに整理された。ところで, 我が国 の学校理科において, 小学校第 3 学年理科単元「昆 虫と植物」で扱う「昆虫の体のつくり」は, 多様性 と共通性という視点で生き物を捉えるとともに, 比 較・照合等を通した生物分野における資質・能力の 育成を図る最初の機会の一つである。具体的には, 昆虫の体のつくりに関する概念の内包（「昆虫の体 は, 頭・胸・腹の三つの部分に分かれている」や， 「昆虫の胸には 6 本のあしがある」という命題）等 の学習を通して, 多様な生き物を, 昆虫とその他の 生き物とに分類するための活動等が挙げられる。こ

\footnotetext{
${ }^{1}$ 山梨大学大学院総合研究部

${ }^{2}$ 山梨大学大学院教育学研究科
}

うした昆虫の体のつくりを通した子どもの資質・能 力を育成しょうとする思潮は，諸外国においても垣 間見ることができ，例えば米国の小学校理科教科書 (Badders et al., 2007 ; Dispezio et al., 2015) において も，詳細に取り上げられている。

一方，昆虫の体のつくりに関する授業設計には不 可欠である, 昆虫に関わる認識調査研究も多数遂行 されてきた。例えば，小学生に対して，アリやチョウ の描画による調查研究（例えば, 岩下, 2001 ; 矢田, 2005 ；上岡, 2009 ; 市川, 2009 ; Cinici, 2013）や, チョウとトンボの胸部に 6 本のあしを描画させる調 查研究 (日置 - 星野, 2007 ; 山野井 · 大坂 -及川, 2015), 及び昆虫の体のつくりに関する概念の内包に ついて, 自由記述法や描画法によって調査した研究 (Shepardson, 2002) 等が挙げられる。これらの一連 の既存研究により, 昆虫の外部形態や昆虫概念の内 包に対する小学生の低い認識状態が報告されている。

また, 並行して筆者らも, 小学生や小学校教員志 望学生を対象にして, 昆虫に関する認識調査研究を 継続的に遂行してきた。例えば，松森（2000）や松 森・佐藤・望月（2014）では，上述した既存研究と 
類似した手法で, 小学生にアリやチョウの描画を求 める調査を行い, その非科学性を指摘している。ま た，松森・菅沼・佐久間（2013）では，小学校教員 志望学生に対して, 背面から描いた計 9 種類の生き 物（計 6 種類の昆虫と計 3 種類のその他の生き物） の体のつくりに関する認識状態を調査している。結 果として, 計 6 種類すべての昆虫の体を三つの部分 (頭部・胸部・腹部) に正しく分けることができた学 生は僅か $1 \%$ あっあたことや, 前・中胸部の境界で 胸部と腹部とを分ける学生が計 5 種類の昆虫で $80 \%$ 以上を占めること等を明らかにしている。その上で, 調査結果の分析に基づきながら, あしの数に立脚し た昆虫に関する学習指導例を紹介している。さらに, 佐々木・佐藤・塚原・松森（2018）では, 小学校第 $2 \cdot 3$ 学年を対象にして, Shepardson（2002）と類似
した手法で昆虫の体のつくりに関する概念の内包を 調査している。結果として, 本概念の内包を科学的 に説明できた小 2 は皆無であり，小 3 でも約 $30 \%$ に とどまることを報告するとともに，昆虫に関する学 習指導を再構成するための視点等を提案している。

しかしながら, 上述した既存研究においては, 多 様な問題場面のもとで調查が行われている一方, 提 示される昆虫の種数が限定されていたり, 昆虫のあ しのつく位置の判別が困難な背面側の描画が使用さ れていたりする等の問題点が挙げられる。また, 子 どもが, 種々の生き物に対して, 昆虫の体のつくり に関する概念の内包を適用できるか否かも明らかに されていない。さらに, 昆虫に関する学習指導の展 開例や視点等が挙げられているものの, 構造化され た学習指導方策の提案には至っていない。加えて,

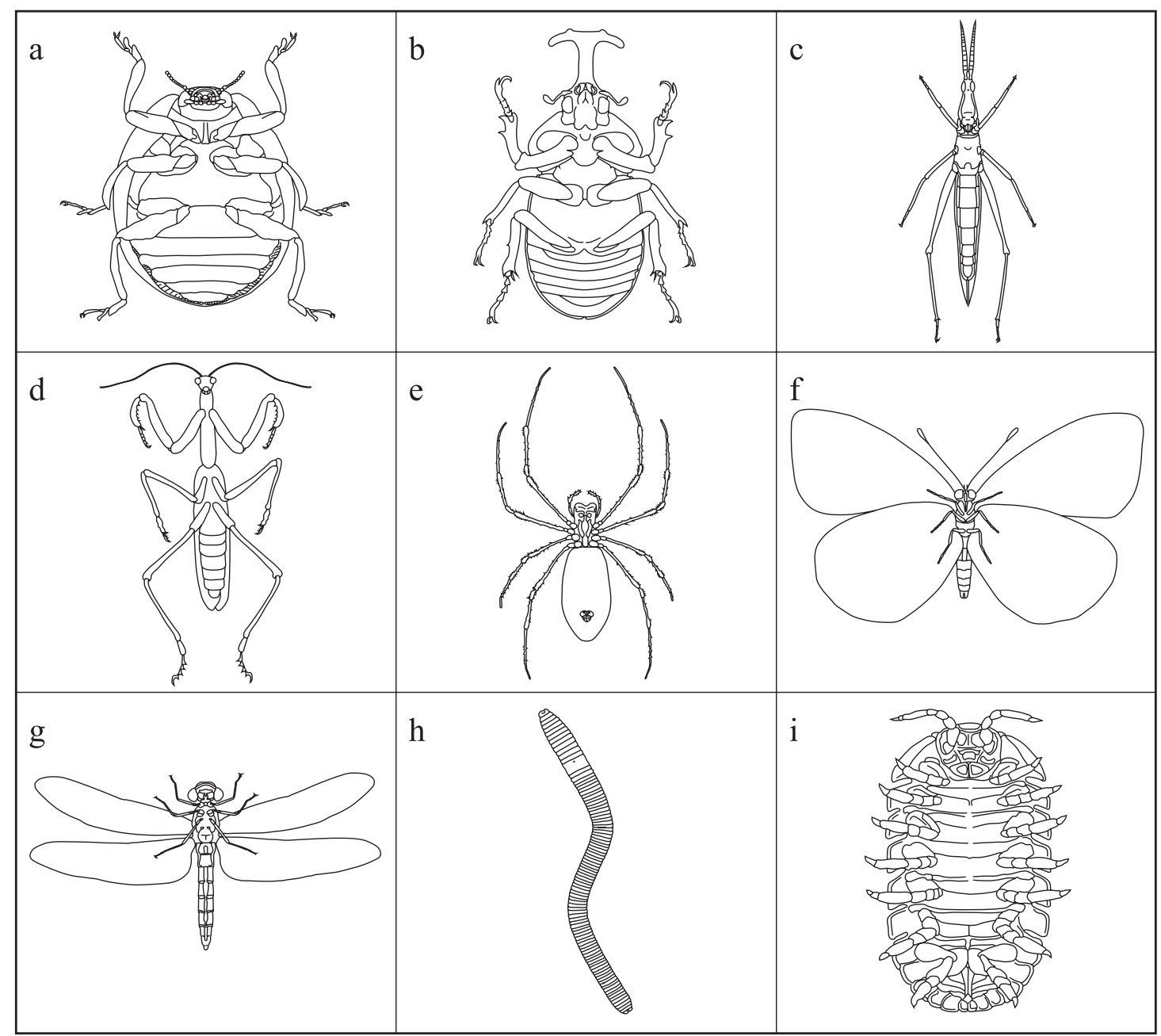

図 1 調査対象とした腹面から描いた計 9 種類の生き物 
昆虫に関する学習指導と, その指導を通して育成す べき資質・能力との連関について明らかにすること も，契緊の課題となっている。

そこで本研究では, 本単元を学習前の第 2 学年と, 学習後の第 3 学年の子どもを対象に, 腹面から描い た計 9 種類の生き物を題材として, 生物分野の学習 で身に付けさせるべき資質・能力の一つである昆虫 概念の認識状態の詳細な把握を試みることにした。 得られた知見に基づき, 昆虫概念の育成を志向した 学習指導方策について提案する。

\section{2. 認識調查の概要}

\section{1 調查の目的}

・学習前後の小学校第 $2 \cdot 3$ 学年を対象にして, 腹面 から描いた昆虫の体のつくりに対する子どもの認 識状態を把握する。

・調査結果等に基づき, 昆虫概念の育成を志向した 学習指導方策について提案する。

\section{2 調査の期日及び対象}

2017 年 2 月と 3 月にかけて, 山梨県内の小学校第 2 学年 126 人 (男 70 人, 女 56 人), 第 3 学年 125 人 (男 63 人, 女 62 人) の計 251 人を対象に実施した。

\section{3 調査に使用する生き物の選定}

調查に使用する計 9 種類の生き物（図 1）は, 岩 間・松原・下條（2008）を参考にし, 文部科学省検 定済小学校第 $3 \sim 6$ 学年理科教科書（計 6 社）に掲載 数の多い節足動物門昆虫綱に属する計 6 種を選定し た。具体的には, 甲虫目（「ナナホシテントウ（a)」 と「ヤマトカブトムシ (b)」) と直翅目（「ショウ リヨウバッ夕 (c)」と「オオカマキリ (d)」) の各 2 種, 及び鱗翅目「モンシロチョウ (f)」と蜻蛉目 「アキアカネ $(\mathrm{g}) 」 の$ 各 1 種である。

さらに, 計 6 社の文部科学省検定済小学校第 3 学 年理科教科書（有馬ほか, 2017 ; 石浦ほか, 2017 ; 癸生川ほか, 2017 ; 毛利ほか, 2017 ; 霜田ほか, 2017 ; 養老ほか, 2017）において, 共通して揭載さ
れている昆虫以外の生き物も取り上げた。具体的に は，節足動物門クモ鋼クモ目「ジョロウグモ (e)」, 及び軟甲鋼ワラジムシ目「オカダンゴムシ（i）」）か ら各 1 種の計 2 種である。加えて, 松森ら (2013) の調査において選定されていた無脚な生き物である 環形動物門貧毛鋼 1 種「ヒトッモンミミズ (h)」も 含めた。なお，図 1 に掲載した計 9 種類の生き物の 腹面側の描画は, 上述した計 6 社の理科教科書, 及 び各種図鑑（石塚，2014；日高，1989）を参考にし て，筆者らが作成した。

\section{4 調查の内容及び方法}

調査内容は，表 1 に示した通り計 9 の質問からな る。まず質問 1〜3 は, 異なる質問紙（使用時は B4 判）に，それぞれ質問文とともに，図 1 の計 9 種類 の生き物を可能な限り拡大して提示し, 計 3 枚を 1 セットにして配布した。具体的には, 計 9 種類の生 き物のうち, 質問 1 では見聞経験のある生き物の描 画に○, 質問 2 では各生き物の名称の記入を求めた。 また，質問 3 は計 9 種類の生き物のうち，昆虫だと 思う描画に○を付すものである。

質問 4 9 は, 図 1 に示した計 9 種類の生き物のう ち, すべての昆虫計 6 種類（a， b , c , d , f, 及び $\mathrm{g}$ ) を取り上げ, 各昆虫の頭部・胸部・腹部を, 異なる 色鉛筆 (赤・青・緑) で囲むように求めるものであ る。具体的には，表 1 の質問文とともに，上述した 計 6 種類の昆虫を拡大した描画を別々の質問紙（使 用時は B5 判）に 1 種類ずつ示し, 計 6 枚を 1 セッ トにして配布した。

なお，回答に際して，質問紙中に描かれた昆虫の 大きさは実際の大きさとは異なること等を口頭で伝 えた上で, 1 問ずつ問題文を復唱させながら実施し た。また，記入済みの質問 1〜3の質問紙を回収した 後, 質問 4〜9の質問紙を配布して記入を求めた。

\section{3. 調査の結果と考察}

3.1 質問 1 (生き物に対する見聞経験) の回答分析

質問 1 に対する回答の単純集計（生き物に対する

表 1 子どもに提示した質問文と調査内容

\begin{tabular}{|c|c|c|}
\hline \multicolumn{2}{|r|}{ 子どもに提示した質問文 } & 調査内容 \\
\hline 質問 1 & 「知っているかな？」 & 計 9 種類の生き物に対する見聞経験について \\
\hline 質問 2 & 「何という名前かな？」 & 計 9 種類の生き物の名称に対する認識について \\
\hline 質問 3 & 「こん虫は, どれかな？」 & 昆虫とその他の生き物との分類について \\
\hline 質問 4 9 & 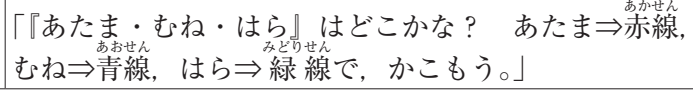 & $\begin{array}{l}\text { 腹面から描いた計 } 6 \text { 種類の昆虫の体のつくり } \\
\text { (頭部・胸部・腹部) の認識について }\end{array}$ \\
\hline
\end{tabular}




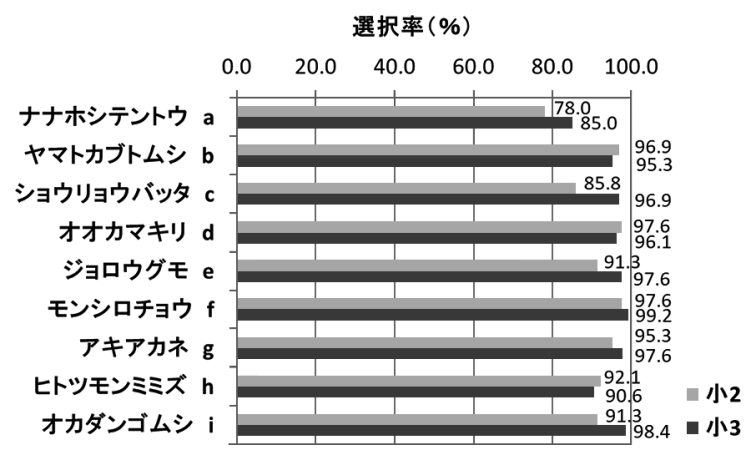

図 2 質問 1 の単純集計（生き物に対する見聞経験）

見聞経験）を図 2 に示す。図 2 を一覧すれば分かる ように, 計 9 種の生き物に対する選択率は, 両学年 において約 80\%以上であった（回答率は $100 \%$ ）。天 井効果（海保, 1986）と判断して, 学年間及び生き 物の種間の統計的な差異については言及を避けるが, 両学年の多くの子どもが, 計 9 種類の生き物に対し て見聞経験を有していた。

\section{2 質問 2 (生き物の名称に対する認識) の回答分析}

計 9 種類の生き物の名称に関する子どもの回答に はさまざまな表記 (平仮名, 片仮名, 及び漢字等) が用いられていたが，名称に誤りがない限り正答と した。また，本調査で使用した描画は生き物の腹面 側であることから，種の同定が難しい点を考慮し， 目・科・属レベルの名称を示す回答も正答に含めた。

図 3 に, 質問 2 の正答率の単純集計（生き物の名 称の正答率）を示した（回答率は $100 \%$ ）。各生き物 の名称の正答率は, 両学年ともに約 40～100\%の範 囲にあり，全問正答者は小 2 で 37 人 $(29.4 \%)$, 小 3 で 69 人 $(55.2 \%)$ であった。「ナナホシテントウ (a)」を除く全ての生き物について, 両学年ともに 約 $80 \%$ 以上が正答であり，質問 1 （生き物に対する 見聞経験）の結果も含み合わせると，両学年ともに，

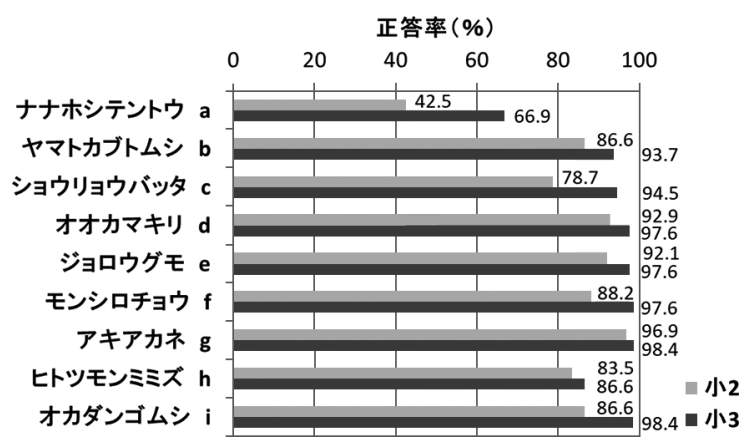

図 3 質問 2 の単純集計（生き物の名称の正答率）
本調査で扱った計 9 種類の生き物に対する知名度は 高いものと推察される。

また，「ナナホシテントウ（a)」では，小 3 の正答

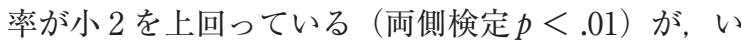
ずれも $70 \%$ に達していない。学年間における正答率 の差異の原因としては，小 3 の子どもに生き物の体 のつくりに関する既習知識が存在し，回答に適用し たことが考えられる。そして両学年に認められたこ とであるが, 低い正答率の要因には, カブトムシの メスやカナブンと誤認した子どもが多数表出したこ とを挙げることができる。さらに，質問紙上におい て「ヤマトカブトムシ (b)」の雄の隣に「ナナホシ テントウ（a)」の描画が配置されていたことも䛊答 が多く表出した一因と推察される。

\section{3 質問 3 （昆虫とその他の生き物との分類）の回 答分析}

図 4 に, 質問 3 の単純集計（昆虫と認識した子ど もの割合）を示した（回答率は $100 \%) 。$ 本質問の正 答率は小 2 で約 60 ～ $80 \%$ の間を推移し，小 3 では $80 \%$ 以上であった。また，両学年間の正答率には, 全ての生き物において有意差が認められた（両側検 定 $p<.05)$ 。まず，特徵的なことは，本単元を学習 前の小 2 であっても,「ヤマトカブトムシ (b)」の正 答率が $80 \%$ 以上に及んだと言うことである。カブト ムシが子ども達にとって馴染みの高い昆虫の上位に 挙げられていること（八木，2010）等からも，この 結果は領けるところである。

一方, 小 2 の場合,「ヤマトカブトムシ (b)」以外 の計 8 種の生き物については, 誤答者が約 25〜 40\% 存在するが，少なくとも $60 \%$ 以上が正しく分類して いることが読み取れる。換言すれば，小学校理科に おいて未習であっても, 小 2 の相当数が, 本研究で 取り上げた各生き物を，昆虫とその他の生き物とに 分類可能であることを示している。その要因の一つ

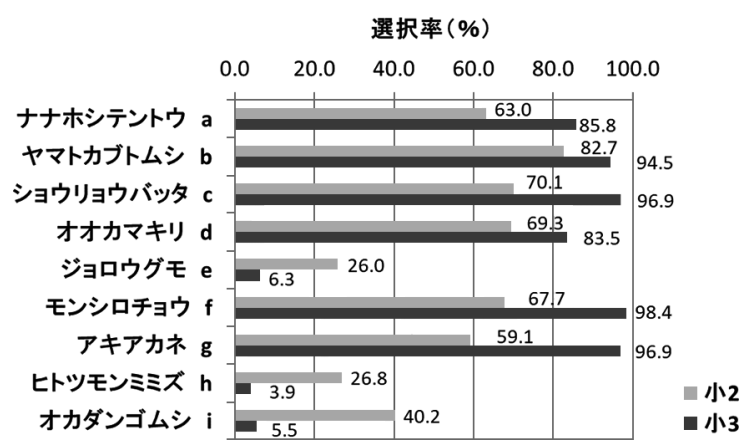

図4質問3の単純集計（昆虫と認識した子どもの割合） 
として，腹面側からモノクロームで描写した計 9 種 類の生き物（図 1）を挙げることができる。頭部・ 胸部・腹部の位置については次の質問 4 9 取り上げるが，実際の生き物の体色や運動等にとら われることなく，各生き物を比較・照合した結果， 「あしが 6 本ついているのが昆虫ではないか」という 昆虫の共通性の一つを見い出したものと推察される。

その一方，小 3 に拈いては約 15\%が，「ナナホシ テントウ（a)」や「オオカマキリ（d）」を昆虫とし て認識していない。既習であっても「昆虫の胸には 6 本のあしがある」という命題を保持していない子 ども，もしくは本命題を保持していたとしても適用 するまでに至らなかった子どもだと考えられる。

\section{4 質問 $4 \sim 9$ （腹面から描いた昆虫の体のつくり の認識) の結果と考察}

\subsection{1 質問 $4 \sim 9$ の全体的傾向}

両学年の 251 人全てが何らかの回答を記してお り（回答率は 100\%），表 2 には質問 4〜9の単純集 計（頭部・胸部・腹部に対する科学的に正しい回 答）を示した。また, 計 6 種類全ての昆虫の体を, 三つの部分（頭部・胸部・腹部）に正しく分けるこ とができた小 2 は皆無であり, 小 3 においても 23 人 $(18.4 \%)$ のみであった。さらに, 表 2 に示す通 り, 各昆虫の正答率は, 小 2 で $10 \%$ 未満, 小 3 でも 約 45〜 65\%であり, 全ての昆虫において学年間で有 意差が認められた（両側検定 $p<.01 ） 。$ 既習の小 3 の $35 \%$ 以上が，計 6 種類のいずれの昆虫においても 䛊答であり，昆虫によっては正答率に $20 \%$ 前後もの 開き（モンシロチョウの $63.5 \%$ とカマキリの 44.8\%) が存在した。

ところで，子どもから得られた回答は多様であっ た。そこで，計 4 人の理科教育研究者（筆者ら）の 合意に基づきながら, 回答結果の分類を試みた。具 体的には, 頭部・胸部・腹部（類型 $\mathrm{i} \sim$ iii）の三つ

表 2 質問 4 9 の単純集計（頭部・胸部・腹部に対す る科学的に正しい回答)

人数 $(\%)$

\begin{tabular}{|c|c|c|c|c|c|c|}
\hline $\begin{array}{r}\text { 質問 } \\
4 \sim 9\end{array}$ & $\begin{array}{l}\text { 質問 } 4 \\
\text { (a) }\end{array}$ & $\begin{array}{c}\text { 質問 } 5 \\
\text { (b) }\end{array}$ & $\begin{array}{c}\text { 質問 } 6 \\
\text { (c) } \\
\end{array}$ & $\begin{array}{c}\text { 質問 } 7 \\
\text { (d) }\end{array}$ & $\begin{array}{c}\text { 質問 } 8 \\
\text { (f) }\end{array}$ & $\begin{array}{c}\text { 質問 } 9 \\
\text { (g) }\end{array}$ \\
\hline 小 2 & $\begin{array}{c}4 \\
(3.1)\end{array}$ & $\begin{array}{c}3 \\
(2.4)\end{array}$ & $\begin{array}{c}3 \\
(2.4)\end{array}$ & $\begin{array}{c}1 \\
(0.8)\end{array}$ & $\begin{array}{c}6 \\
(4.7) \\
\end{array}$ & $\begin{array}{c}11 \\
(8.7)\end{array}$ \\
\hline 小 3 & $\begin{array}{c}75 \\
(60.0)\end{array}$ & $\begin{array}{c}74 \\
(59.2)\end{array}$ & $\begin{array}{c}66 \\
(52.8)\end{array}$ & $\begin{array}{c}56 \\
(44.8)\end{array}$ & $\begin{array}{c}79 \\
(63.5)\end{array}$ & $\begin{array}{c}72 \\
(57.6)\end{array}$ \\
\hline
\end{tabular}

の部分に分け，各部分ごとに回答の傾向を類型化し た。結果として，表 3 の左端に示したように，頭部 の位置に関する 4 類型（「類型 $\mathrm{i}-$ - 1)」〜 「類型 $\mathrm{i}-$ (4)」, 胸部の位置に関する 9 類型（「類型 ii - (1)」〜「類 型 ii - (9」)，及び腹部の位置に関する 3 類型（「類型 iii- (1)」〜「類型 iii- (3)」) に分類することができた。 また，同じく表 3 には，各類型に対する質問ごとの 学年別該当者数（\%）も合わせて示した。

なお，各類型に該当する典型的な回答を図 5 に示 した。次節以降では，三つの部分（頭部・胸部・腹 部）の各類型に該当する子どもの認識について分析 を加える。

\section{4 .2 質問 $4 \sim 9$ の回答分析}

（1）頭部の位置について（類型 i ）

頭部に関する正答基準としては，胸部や腹部を含 まない胸部より上の体の部分であり，かつ目や口等 の各器官に加えて, 触角や頭角等と頭部との接続部 が含まれることとした。頭部の回答は計 4 類型で あり，正答類型（類型 $\mathrm{i}$ - 1 1)）の該当者（図 5 のア 〜エの○を付した頭部の位置）は，小 2 で約 40〜 $75 \%$ ，小 3 で約 80～100\%を推移しており，いずれ の昆虫でも小 3 の正答率が高い結果となった（両側 検定 $p<.01)$ 。小 2 の誤答が高率な背景としては, 頭部以外の部分や頭部の一部分のみを頭部とみなす 回答（類型 i- (2)〜類型 i- (4)に該当) が多数認めら れたことが挙げられる。

まず，類型 i - (2) は頭角や触角のみを頭部とする 回答であり, 小 3 は $10 \%$ 未満の少数であるものの, 小 2 では「オオカマキリ (d)」と「モンシロチョウ (f)」で約 $10 \%$ ，「ヤマトカブトムシ (b)」と「ショ ウリョウバッタ (c)」では約 20\%存在した。体の最 も上端にある器官等を頭部と判断していることが窅 い知れる回答である（図 5 のカ，キ，ク，及びケの ○を付した頭部の位置)。また，類型 $\mathrm{i}$ - (3)に該当す る回答は，25\%未満であるが両学年に存在した。図 5 のコ，サ，及びシの○を付した頭部の位置のよう に，あしのつく前胸部や中胸部までを含めた回答で あり，あしの接続部分は胸部にあたることに対する 認識が欠落している。

さらに，類型 $\mathrm{i}$ - (4)に該当する，頭部が含まれな い回答（図 5 のソの○を付した頭部の位置）や，頭 部の一部分のみが○で囲われた回答（図 5 のスやセ の○を付した頭部の位置）も存在しており（小 2 で 約 10〜 30\%，小 3 で 10\%未満)，いずれの昆虫でも 小 3 よりも小 2 の該当者が多い（両側検定 $p<.05 ） 。$ 特に小 2 では，本来の頭部とは異なる部分や，頭部 
に含まれる一部の器官（口等）のみを頭部と判断す る回答が散見され, 頭部に対する生物学的認識が不 十分であることが明らかになった。

(2) 胸部の位置について（類型 ii )

図 5 のアやイの○を付した胸部の位置に該当し, 頭部や腹部を含まず，頭部と腹部の間の部分を囲ん
でいる回答（計 6 本のあしと胸部との接続部分を全 て含む）を正答とした。正答類型である ii - (1)に該 当する小 2 は, 「モンシロチョウ（f)」や「アキアカ ネ (g)」では約 $20 \%$ に達しているが, それ以外の昆 虫ではいずれも $5 \%$ 未満であった。小 2 は, 自らの (ヒトの) 胸部の位置から類推していることが推察さ

表 3 腹面から描かれた計 6 種類の昆虫の体のつくり（頭部・胸部・腹部）の回答類型（人数 $(\%))$

\begin{tabular}{|c|c|c|c|c|c|c|c|c|c|}
\hline \multirow{2}{*}{\multicolumn{3}{|c|}{ 類型 }} & \multirow[t]{2}{*}{ 質問 4(a) } & \multirow[t]{2}{*}{ 質問 5 (b) } & \multirow[t]{2}{*}{ 質問 6（c) } & \multirow[t]{2}{*}{ 質問 7 (d) } & \multirow[t]{2}{*}{ 質問 8（f） } & \multirow[t]{2}{*}{ 質問 9（g） } & \multirow[t]{2}{*}{$\begin{array}{c}\text { 図 } 5 \text { との } \\
\text { 対応 }\end{array}$} \\
\hline & & & & & & & & & \\
\hline \multirow{8}{*}{$\begin{array}{l}\mathrm{i} \\
. \\
\text { 頭 } \\
\text { 部 }\end{array}$} & \multirow{2}{*}{$\begin{array}{l}\text { (1)科学的に正しい回答 } \\
\text { (頭部) }\end{array}$} & 小 2 & $96(76.2)$ & $77(61.2)$ & $49(38.9)$ & $67(53.2)$ & $69(54.7)$ & $60(47.6)$ & \multirow{2}{*}{$\begin{array}{c}\text { ア, イ, } \\
\text { ウ, エ, オ }\end{array}$} \\
\hline & & 小 3 & $122(97.6)$ & $108(86.4)$ & $105(84.0)$ & $105(84.0)$ & 112 (89.6) & $98 \quad(78.4)$ & \\
\hline & \multirow{2}{*}{$\begin{array}{l}\text { (2)角もしくは, 触角を頭 } \\
\text { 部とする回答 }\end{array}$} & 小 2 & $1(0.8)$ & $24(19.0)$ & 22(17.4) & $11(8.7)$ & $15(11.9)$ & & \multirow{2}{*}{$\begin{array}{l}\text { カ, キ, } \\
\text { ク, ケ }\end{array}$} \\
\hline & & 小 3 & & 2(1.6) & $1(0.8)$ & $1(0.8)$ & $4(3.2)$ & & \\
\hline & \multirow{2}{*}{$\begin{array}{l}\text { (3)胸部及び胸部の一部を } \\
\text { 含む頭部 }\end{array}$} & 小 2 & $2(1.6)$ & $10(7.9)$ & $18(14.3)$ & $25(19.8)$ & $19(15.1)$ & $28(22.2)$ & \multirow{2}{*}{ コ, サ, シ } \\
\hline & & 小 3 & $3(2.4)$ & $11(8.8)$ & $13(10.4)$ & $15(12.0)$ & $6(4.8)$ & $15(12.0)$ & \\
\hline & \multirow{2}{*}{$\begin{array}{l}\text { (4)頭部及び頭部の一部の } \\
\text { 欠損（類型 i - (2)・3 } \\
\text { を除く） }\end{array}$} & 小 2 & $27(21.4)$ & 15 (11.9) & $37(29.4)$ & 23 (18.3) & $23(18.3)$ & $38(30.2)$ & \multirow{2}{*}{ ス, セ, ソ } \\
\hline & & 小 3 & & 4(3.2) & $6(4.8)$ & $4(3.2)$ & $3(2.4)$ & $12(9.6)$ & \\
\hline & \multirow{2}{*}{$\begin{array}{l}\text { (1)科学的に正しい回答 } \\
\text { (胸部) }\end{array}$} & 小 2 & $4(3.2)$ & $4(3.2)$ & $5(4.0)$ & $3(2.4)$ & 31 (24.6) & $26(20.6)$ & \multirow{2}{*}{ ア, イ } \\
\hline & & 小 3 & $75(60.0)$ & $74 \quad(59.2)$ & $72(57.6)$ & 57 (45.6) & $81 \quad(64.8)$ & $78 \quad(62.4)$ & \\
\hline & \multirow{2}{*}{$\begin{array}{l}\text { (2)前胸部のみを胸部とし } \\
\text { た回答 }\end{array}$} & 小 2 & 23 (18.3) & $29(23.0)$ & $24(19.0)$ & $48 \quad(38.1)$ & 9(7.1) & $1(0.8)$ & \multirow{2}{*}{ 力, キ } \\
\hline & & 小 3 & $3(2.4)$ & $14(11.2)$ & $2(1.6)$ & $43(34.4)$ & & & \\
\hline & \multirow{2}{*}{$\begin{array}{l}\text { (3)中胸部のみを胸部とし } \\
\text { た回答 }\end{array}$} & 小 2 & $12(9.5)$ & $15(11.9)$ & $34(26.9)$ & $8(6.3)$ & $5(4.0)$ & $8(6.3)$ & \multirow{2}{*}{ ク } \\
\hline & & 小 3 & $13(10.4)$ & $2(1.6)$ & $14(11.2)$ & $3(2.4)$ & $1(0.8)$ & $1(0.8)$ & \\
\hline & \multirow{2}{*}{$\begin{array}{l}\text { (4)後胸部のみを胸部とし } \\
\text { た回答 }\end{array}$} & 小 2 & & 2(1.6) & & & $6(4.8)$ & $8(6.3)$ & \# \\
\hline & & 小 3 & & $1(0.8)$ & & & $1(0.8)$ & $1(0.8)$ & T) \\
\hline & (5)前胸部＋中胸部を胸部 & 小 2 & $16(12.6)$ & $9(7.1)$ & $4(3.2)$ & & $32(25.4)$ & $12(9.5)$ & \\
\hline \multirow{3}{*}{$\begin{array}{l}\text { 囟 } \\
\text { 部 }\end{array}$} & とした回答 & 小 3 & $8(6.4)$ & $10(8.0)$ & $9(7.2)$ & & $3(2.4)$ & $1(0.8)$ & V \\
\hline & (6)中胸部+後胸部を胸部 & 小 2 & $5(4.0)$ & $4(3.2)$ & $21(16.7)$ & $15(11.9)$ & $8(6.3)$ & $30(24.0)$ & \\
\hline & とした回答 & 小 3 & $6(4.8)$ & $14(11.2)$ & $18(14.4)$ & $17(13.6)$ & & $8(6.4)$ & \\
\hline & & 小 2 & $9(7.1)$ & $6(4.8)$ & $4(3.2)$ & $2(1.6)$ & $2(1.6)$ & $2(1.6)$ & \\
\hline & (7) 複数固所存在する胛部 & 小 3 & $1(0.8)$ & $1(0.8)$ & $1(0.8)$ & $1(0.8)$ & $1(0.8)$ & $1(0.8)$ & \\
\hline & 8腹部及び腹部の一部を & 小 2 & $5(4.0)$ & & $6(4.8)$ & $2(1.6)$ & $18(14.3)$ & $8(6.4)$ & \\
\hline & 含む胸部 & 小 3 & $9(7.2)$ & $1(0.8)$ & $8(6.4)$ & & $33(26.4)$ & $20(16.0)$ & \\
\hline & $\begin{array}{l}\text { (9胸部及び胸部の一部の } \\
\text { 个垣 }(\text { 頪刑 }\end{array}$ & 小 2 & $52(41.3)$ & $57(45.2)$ & $28(22.2)$ & $48(38.1)$ & $15(11.9)$ & $31 \quad(24.6)$ & \\
\hline & を除く) & 小 3 & $10(8.0)$ & $8(6.4)$ & $1(0.8)$ & $4(3.2)$ & $5(4.0)$ & $15(12.0)$ & \\
\hline & (1)科学的に正しい回答 & 小 2 & $26(20.6)$ & $19(15.1)$ & $39(31.0)$ & $19(15.1)$ & $11(8.7)$ & $25(19.8)$ & ア, イ, \\
\hline & (腹部) & 小 3 & $98 \quad(78.4)$ & $92(73.6)$ & $100(80.0)$ & $72(57.6)$ & 93(74.4) & $86(68.8)$ & コ, セ, ソ \\
\hline & (2)胸部及び胸部の一部を & 小 2 & $36(28.6)$ & $27(21.4)$ & $14(11.1)$ & $33(26.2)$ & $21(16.7)$ & $18(14.3)$ & \\
\hline IIII & & 小 3 & $6(4.8)$ & $20(16.0)$ & $10(8.0)$ & $42(33.6)$ & $4(3.2)$ & $6(4.8)$ & \\
\hline 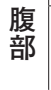 & (3)腹部及び腹部の一部の & 小 2 & $64(50.8)$ & $80(63.5)$ & $73(57.9)$ & $74(58.7)$ & $94 \quad(74.6)$ & $83(65.9)$ & $\begin{array}{l}\text { ウ, エ, } \\
\text { オ, ク, }\end{array}$ \\
\hline & $<)$ & 小 3 & $21 \quad(16.8)$ & $13(10.4)$ & $15(12.0)$ & $11(8.8)$ & $28(22.4)$ & $33(26.4)$ & $\begin{array}{l}\text { ケ, サ, } \\
\text { シ, ス }\end{array}$ \\
\hline
\end{tabular}

注）尚，表中の右端の片仮名（ア〜ソ）は図 5 のそれらと対応している。 


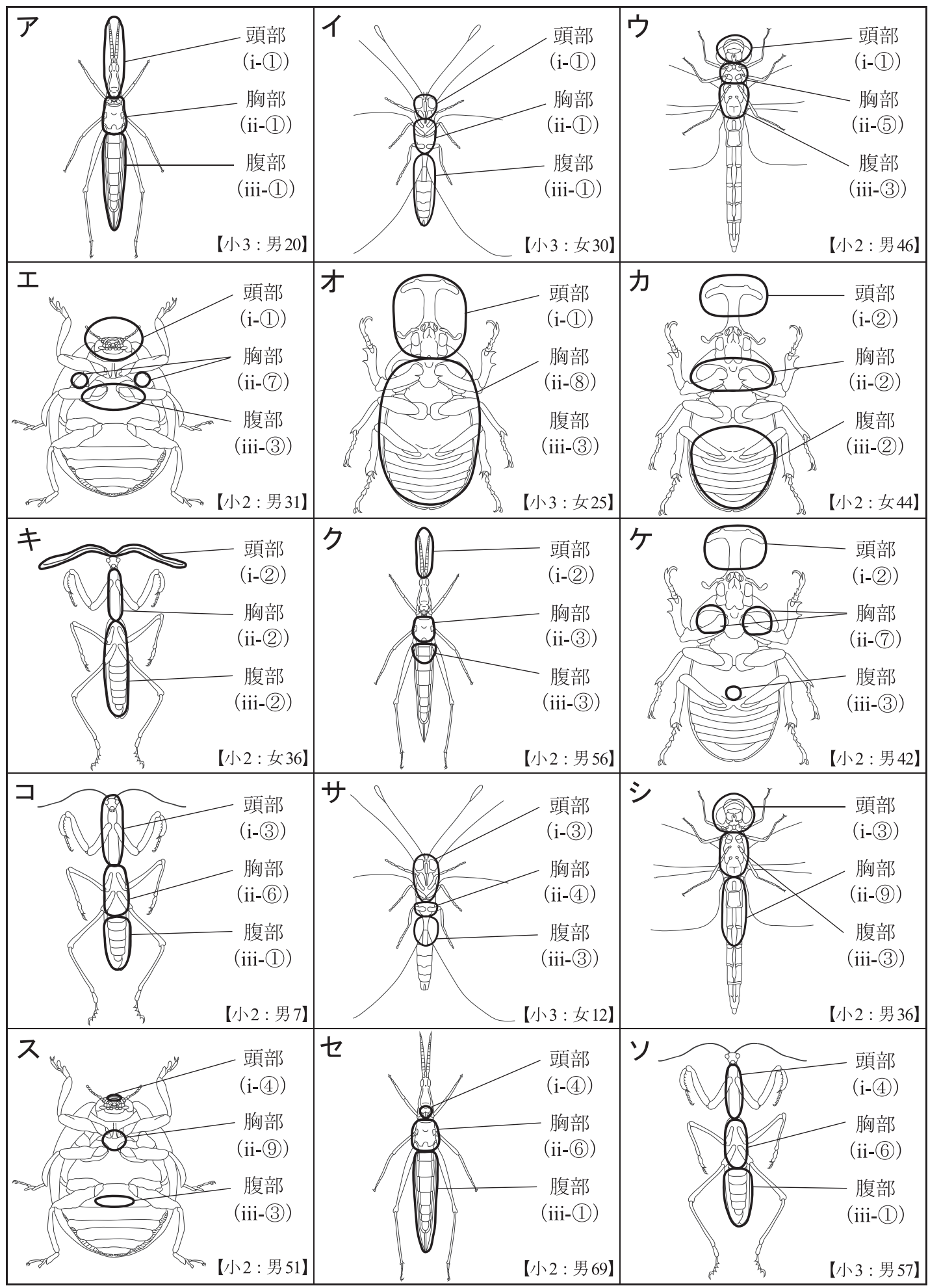

図 5 質問 4 9 の回答例

注）尚，体の各部分（頭部・胸部・腹部）に添えられた括弧内の類型は，表 3 の左端のそれらと対応している。また，

モンシロチョウ (イ・サ), 及びアキアカネ（ウ・シ）については，羽を一部削除している。 
れ，全体として体の上部付近を胸部とみなす傾向が 認められた。また,「モンシロチョウ (f)」や「アキ アカネ $(\mathrm{g}) 」$ は, 計 6 本のあしと胸部との接続部が 体の上部かつ中心付近に集まっていること等から, 他の昆虫よりも正答率が高くなったものと考えられ る。一方で, 既習の小 3 でも正答率は約 45〜 65\%で

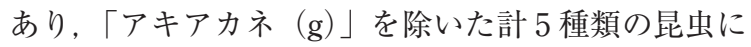
おいて, 頭部・胸部・腹部のうちで最も低い正答率 となった（両側検定 $p<.05 ） 。$

胸部の正答が他の部分に比べて低率であった背景 には, 松森ら（2013）が指摘しているように, 前胸 部・中胸部・後胸部の三つの体節の境界で, 胸部と その他の部分 (頭部・腹部) とを区分していること 等が挙げられる。また, 具体的には， 5 類型（類型 ii - (2)〜 ii - (6)）が該当する。例えば, 類型 ii - (2) (図 5 のカやキの○を付した胸部の位置) の「ヤマト カブトムシ (b)」や「オオカマキリ (d)」では, 両 学年ともに各約 10〜 25\% と約 35〜 40\%存在してお り, 既習の小 3 でも多数該当した。前胸部の発達や, 前・中胸部の境界が構造上明確であること, さらに 中・後胸部と腹部とが同一幅で連続していること等 から，前胸部のみを胸部と誤認した回答である。結 果として，表 4 に示したように，三つの体節（前・ 中・後胸部）の境界を, 胸部とその他の部分（頭部 や腹部）との境界だと判断した回答（5 類型, 類型 ii - (2)〜類型 ii - (6) ) は, 各昆虫に扔いて小 2 で約 45 65\% と誤答理由の半数前後にあたる。また, 小 3 でも「オオカマキリ (d)」は50\%に達し,「ナナ ホシテントウ (a)」, 「ヤマトカブトムシ (b)」, 及び 「ショウリョウバッ夕 (c)」も約 25～35\%に達する。 両学年において, 胸部の三つの体節 (前・中・後胸 部）に関わる誤答が散見されており, 胸部に対する 䛊答の要因の一つであることが判明した。

また, 類型 ii - (7) (小 2 の約 10\%未満) には, ヒ トの乳房の位置から類推して, 2 カ所に○をつけた

表 4 類型 $\mathrm{ii}$ - (2) 類型 $\mathrm{ii}$ - (6)の該当者数

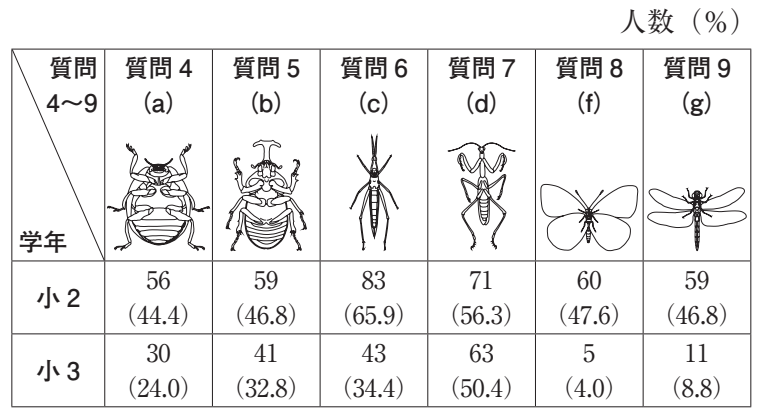

と推定される回答（図 5 のエやケの○を付した胸部 の位置) 等が挙げられる。さらに, 類型 $\mathrm{ii}$ - 8) (図 5 のオの○を付した胸部の位置) では,「モンシロチョ ウ (f)」や「アキアカネ (g)」の該当者が小 2 より も小 3 で多く（両側検定 $p<.05 ）$, 小 2 でそれぞれ 約 $15 \%$ と $5 \%$ ，小 3 では約 $25 \%$ と $15 \%$ であった。こ の 2 種類は, 前述した計 6 本のあしが体の上部中央 に集まっていること等から小 2 の正答率が他の昆虫 よりも高かったことや，小 3 は腹部の上方までを含 めて胸部とした回答が多かったこと等に起因するも のと考えられる。

その他, 類型 ii-9は, 小 2 で 10 45\%, 小 3 で も約 $10 \%$ 未満存在し，いずれの昆虫も小 3 よりも小 2 で多数該当した（両側検定 $p<.05 ） 。$ 小 2 の方が 高率だった理由としては，腹部の一部を胸部とした 回答（図 5 のシの○を付した胸部の位置）や，ヒト の胸部を類推し体の上部中央を胸部とする回答（図 5 のスの○を付した胸部の位置）が多かったこと等 が挙げられる。以上，胸部の回答分析を試みてきた

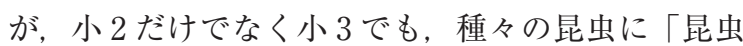
の胸には 6 本のあしがある」という命題を適用でき ず，胸部の位置を正しく示せなかった回答が多数表 出する結果となった。

（3）腹部の位置について（類型 iii）

腹部の正答は，頭部や胸部を含まず，胸部より下 の体の部分（後脚 2 本を含む後胸部より下の部分） をすべて囲んだ回答である（図 5 のア，イ、コ，七， 及びソの○を付した腹部の位置)。計 3 つの類型が 存在し，質問 4 9 を通して正答の類型 iii- (1)に該当 した小 2 は約 10〜30\%，小 3 では約 55〜80\%であ り，いずれの昆虫においても小 2 が小 3 を下回った (両側検定 $p<.01$ )。小 2 の正答が低率であること は，類型 iii- (2)や類型 iii- (3)の該当者が多数存在した ことに起因している。例えば，類型iii- (2)は，腹部 に加え, 胸部もしくはその一部を含む回答が該当し, 図 5 のカやキの○を付した腹部の位置のように, 中 胸部や後胸部も含めて腹部としており，いずれの昆 虫でも小 2 の 10〜 30\%が該当した。一方，小 3 でも 「ヤマトカブトムシ（b)」や「オオカマキリ（d）」で は，それぞれ約 $15 \%$ と $30 \%$ 存在した。本類型に該当 する子どもの多くも，前述したように境界が明確な 前・中胸部間の体節部分で胸部と腹部とを分けてお り, 同一幅で連続した中・後胸部と腹部とを一括り にして, 腹部として判断したものと推察される。

さらに類型iii- (3) は, 腹部もしくはその一部が久 損した回答であり，いずれの昆虫でも小 2 で約 50〜 $75 \%$ と過半数を超え，小 3 でも約 10～25\%存在した 
(図 5 のウ，エ，才，ク，ケ，サ，シ，及びスの○を 付した腹部の位置)。特に小 2 では, 図 5 のクやサ, 及びシのように，腹部の下方末端まで囲わない回答 が散見された。松森ら（2014）において，チョウの 腹部を「おしり」とみなす小学校教員志望学生の存 在が指摘されているように，ヒトの体と同じように 昆虫にも「おしり」があるものと類推した子どもだ と考えられる。

\section{4. 調査結果の総括と今後の指導のあり方}

本章では，前章までの調查結果を総括するととも に，昆虫概念の育成を志向した学習指導方策につい て提案する。

\section{1 調査結果の総括}

松森ら（2013）では，背面から描いた計 6 種類の 昆虫の体のつくりに対する小学校教員志望学生の低 い認識状態を指摘していた。一方，本研究において， 子どもにとってさまざまな種類の昆虫の知名度は高 いものの，あしのつく位置の判別が容易な腹面側の 描画を用いても, 計 6 種類の昆虫の体を三つの部分 (頭部・胸部・腹部) に正しく分けることができた小
2 は皆無であり，小 3 でも約 $20 \%$ のであることが 明らかになった。また，胸部とその他の部分（頭部 や腹部）との境界を，三つの体節（前・中・後胸部） の境界と誤認した回答は，いずれの昆虫でも小 2 で $50 \%$ 前後に上り，小 3 でも計 4 種類の昆虫で約 25〜 $50 \%$ にんだ。松森ら（2013）と本稿とでは調査対 象は異なるものの, 本単元学習直後の小 3 であって も，腹面から描いた昆虫に対して，昆虫の体のつく りに関する概念の内包（「昆虫の体は，頭・胸・腹の 3 つの部分に分かれている」や，「昆虫の胸には 6 本 のあしがある」という命題）自体を保持していない 子ども，もしくは内包を保持していたとしても種々 の生き物に適用するまでに至らなかった子どもが多 数存在する。さらに，各昆虫の正答率では，小 2 で $10 \%$ 未満，小 3 でも約 45～65\%にとどまった。特に, 結果の中で再三指摘したように，「昆虫の胸には 6 本 のあしがある」という命題に対する低い認識状態が, 昆虫の体のつくりに対する非科学的認識を生じさせ る主要因となっていることが判明した。

表 5 は，本研究によって明らかになった子どもの 認識状態を，二つの観点（A：昆虫とそれ以外の生

表 5 昆虫の体のつくりに関連する子どもの認識状態，及び育成を目指す昆虫概念を構成する知識等

\begin{tabular}{|c|c|c|c|c|}
\hline \multirow{2}{*}{\multicolumn{2}{|c|}{ 項目 }} & \multicolumn{2}{|l|}{ 子どもの認識状態 } & \multirow{2}{*}{$\begin{array}{l}\text { 育成を目指す昆虫概念を構 } \\
\text { 成する知識等 }\end{array}$} \\
\hline & & 小 2 & 小 3 & \\
\hline \multicolumn{2}{|c|}{$\begin{array}{r}A: \text { 昆虫とその他の } \\
\text { 生き物との分類 }\end{array}$} & $\begin{array}{l}\text { ·約 } 40 \% \text { が, ナナホシテントウやアキアカネを非昆虫, オカダ } \\
\text { ンゴムシを昆虫と誤認していること } \\
\text { ・約 } 30 \% \text { ジ, ショウリョウバッタ, オオカマキリ, 及びモンシ } \\
\text { ロチョウを非昆虫, ジョロウグモやミミズを昆虫と誤認して } \\
\text { いること }\end{array}$ & $\begin{array}{l}\text { - 約 } 15 \% \text { が, ナナホシテン } \\
\text { トウとオオカマキリを非 } \\
\text { 昆虫と誤認していること }\end{array}$ & $\begin{array}{l}\text { A-1）昆虫には計 } 6 \text { 本のあ } \\
\text { しがあること }\end{array}$ \\
\hline \multirow{6}{*}{$\begin{array}{l}\text { B } \\
\text { 昆 } \\
\text { 虫 } \\
\text { 体 } \\
\text { の } \\
\text { 己 } \\
\text { L } \\
\text { v }\end{array}$} & \multirow[t]{2}{*}{ 頭部 } & 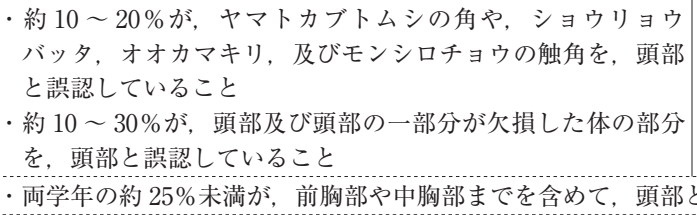 & 誤認していること & \multirow[t]{2}{*}{$\begin{array}{l}\text { B-1）昆虫の体は, 頭部・ } \\
\text { 胸部・腹部の三つの部分 } \\
\text { に分かれていること } \\
\text { B-2）昆虫の頭部は, 胸 } \\
\text { 部の上部分全体であり, } \\
\text { 目, 口, 及び触角等の器 } \\
\text { 官が含まれること }\end{array}$} \\
\hline & & & & \\
\hline & \multirow[b]{2}{*}{ 胸部 } & 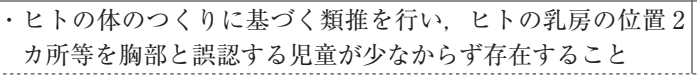 & & \multirow{2}{*}{$\begin{array}{l}\text { B-3）昆虫の胸部は, 計 } 6 \\
\text { 本のあしの接続部分であ } \\
\text { ること } \\
\text { B-4）背腹両面から, 計 } 6 \\
\text { 本のあしの接続部分を観 } \\
\text { 察すること }\end{array}$} \\
\hline & & \multicolumn{2}{|c|}{ 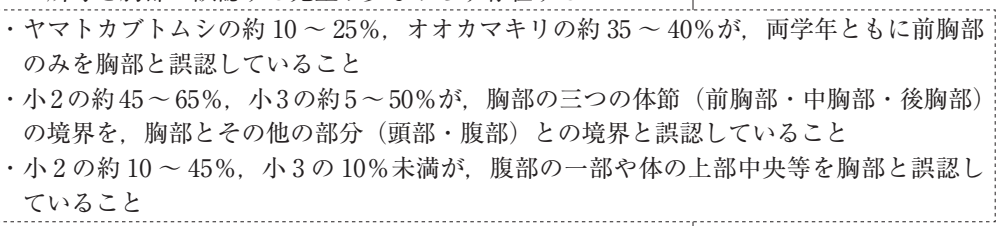 } & \\
\hline & \multirow[b]{2}{*}{ 腹部 } & $\begin{array}{l}\text { ·ヒトの体のつくりに基づく類推を行い, 後胸部 (後脚 } 2 \text { 本) } \\
\text { の上方を腹部と誤認する児童が少なからず存在すること }\end{array}$ & & \multirow{2}{*}{$\begin{array}{l}\text { B-5) 昆虫の腹部は, 胸部 } \\
\text { の下部分全体であり, 内 } \\
\text { 部には胃, 腸等の内臟が } \\
\text { 含まれること }\end{array}$} \\
\hline & & \multicolumn{2}{|c|}{ 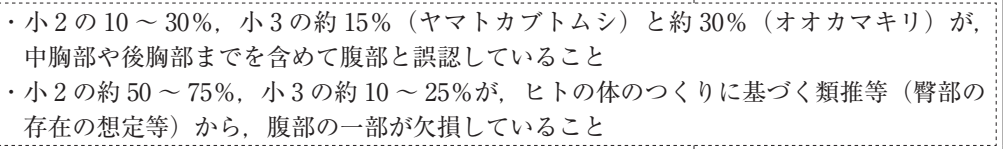 } & \\
\hline
\end{tabular}




\section{表 6 昆虫概念の育成を志向した学習指導方策（案）}

\begin{tabular}{|c|c|c|}
\hline & 各ステップの一連の流れ & $\begin{array}{l}\text { 昆虫概念を構 } \\
\text { 成する知識等 }\end{array}$ \\
\hline$\nabla$ & 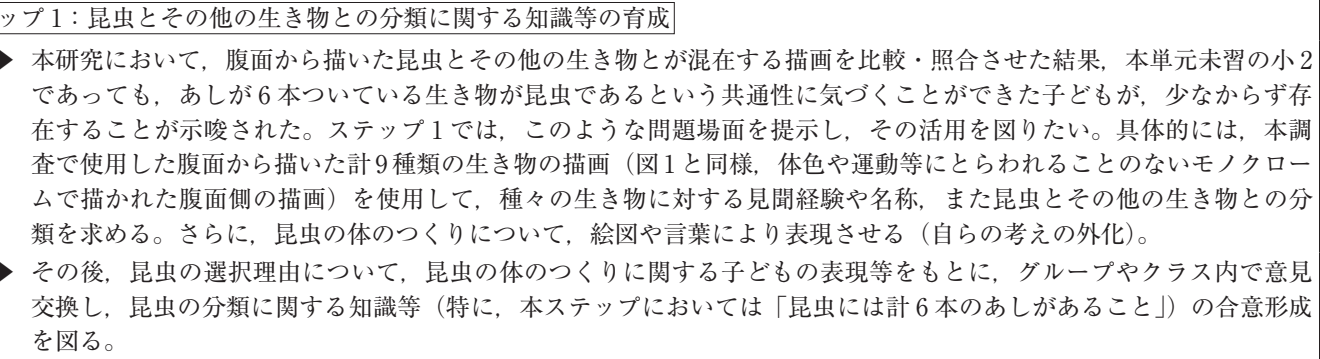 & A-1 \\
\hline$\nabla$ & 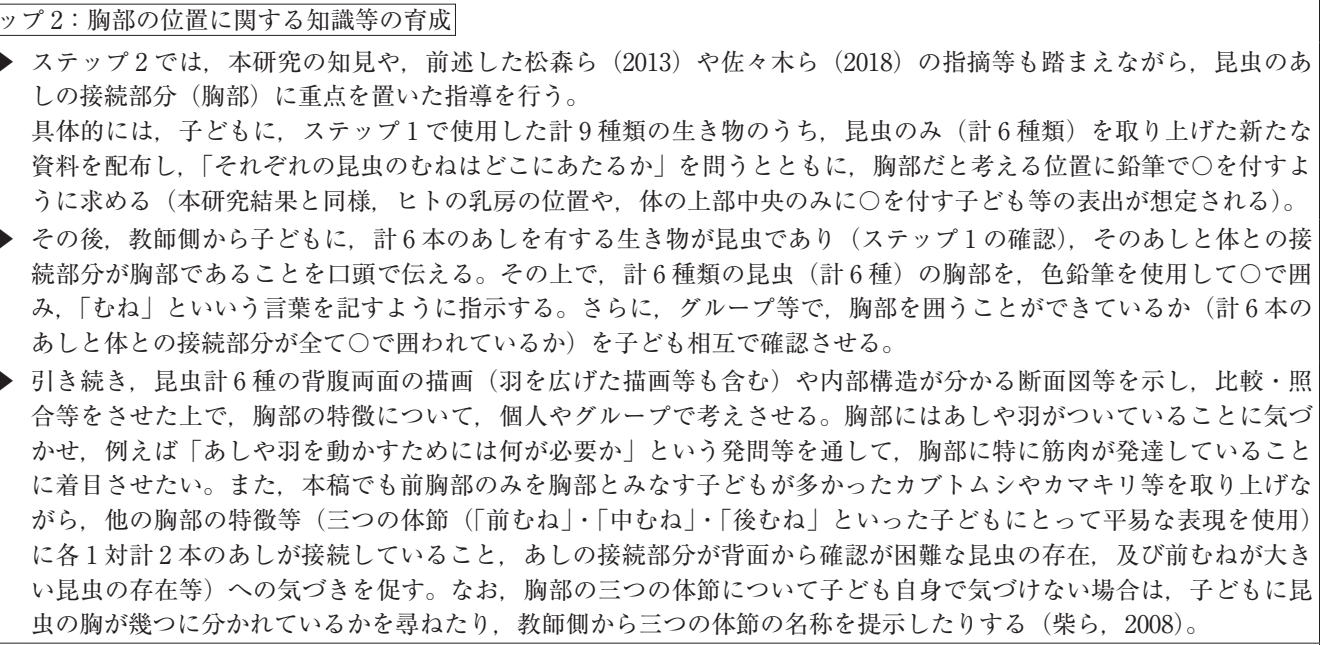 & $\begin{array}{l}\text { B-3 } \\
\text { B-4 }\end{array}$ \\
\hline & 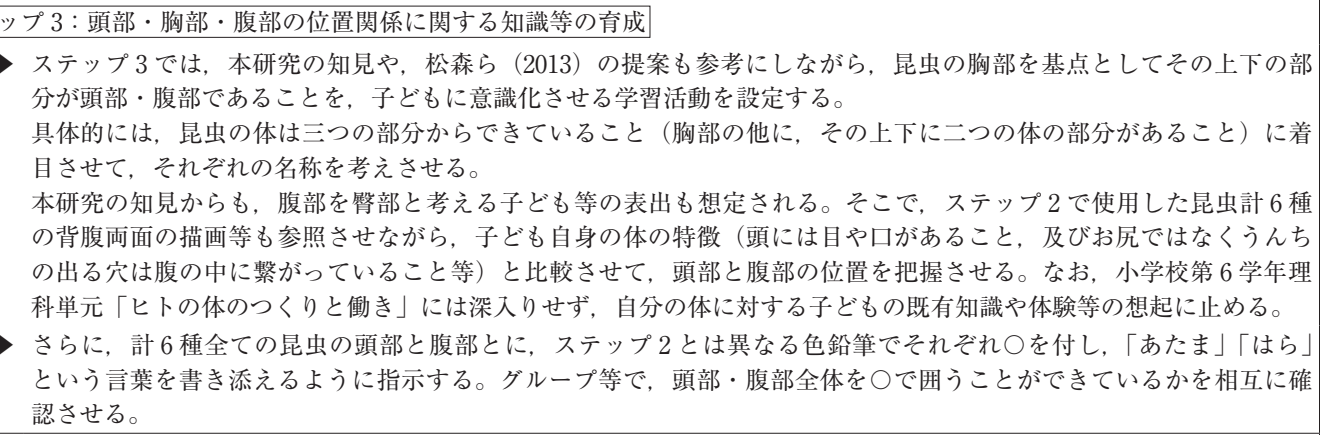 & \\
\hline & 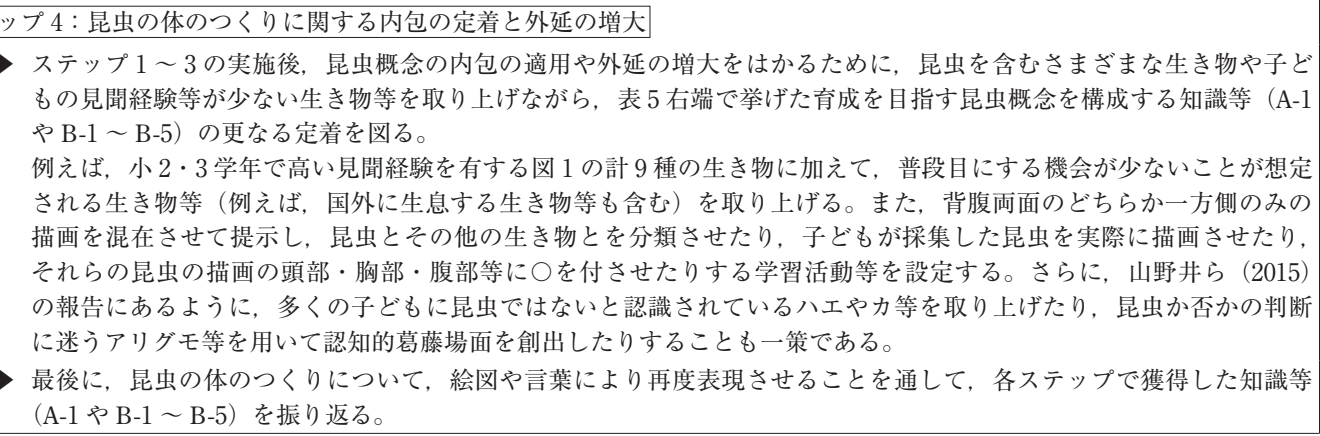 & $\begin{array}{c}\text { A-1 } \\
\text { B-1 } \sim \text { B-5 }\end{array}$ \\
\hline
\end{tabular}

注）尚, 本表の右端の「昆虫概念を構成する知識等」は, 表 5 の右端のそれらと対応している。 
き物の分類, $\mathrm{B}$ ：昆虫の体のつくり）からまとめた ものである。表中の子どもの認識状態の実態を鑑み て, 右端には, 「育成を目指す昆虫概念を構成する知 識等」として A-1〜B-5 までの計 6 項を挙げた。次節 では各項に対応した理科学習指導方策を提案する。

\section{2 昆虫概念の育成を志向した理科学習指導方策に ついて}

上記 4.1 にみる子どもの低い認識状態の克服, 及 び昆虫概念の育成を志向するとともに, 他の既存研 究からの知見を踏まえながら, 昆虫のあしの数や接 続部分 (胸部) 等に重点を置いた学習指導方策を提 案する。具体的には, 表 6 に示したような計 4 のス テップ（ステップ 1：昆虫とその他の生き物との分 類に関する知識等の育成, ステップ $2:$ 胸部の位置 に関する知識等の育成，ステップ 3 : 頭部・胸部・ 腹部の位置関係に関する知識等の育成, ステップ 4: 昆虫の体のつくりに関する概念の内包の定着と外延 の増大）からなる。また, 表 6 の右端には, 各ス テップにおいて取り上げる, 表 5 で抽出した「育成 を目指す昆虫概念を構成する知識等」を記した。

まず，多様な生き物の比較・照合や，昆虫か否か の検討等を通して, 昆虫やその他の生き物の分類に 関する知識等を育成する（ステップ 1)。引き続き， あしの接続部分が胸部であることを説明した上で, 胸部の特徴等を考えさせる活動等を通して, 胸部に 関する知識等を育成する（ステップ 2$)$ 。さらに, 教 師側の支援のもとで, 頭部・腹部について, 内部構 造等を考えさせる活動等を通して, 頭部・胸部・腹 部に関する知識等の育成を図る（ステップ 3 )。最後 に，未知の生き物を取り上げたり，自由記述形式で 昆虫の体のつくりを表現させたりして, 昆虫の体の つくりに関する概念の内包の定着と外延の増大を図 る（ステップ 4）という一連の流れである。

\section{5. 結語に変えて}

今後は, 本研究で明らかとなった昆虫の体のつく りに関する子どもの低い認識状態の改善に向けて, 考案した学習指導方策の有効性の検証等を行ってい かなければならない。特に, 本学習指導方策では, 子どもの低い認識状態を鑑み, 現行の理科教科書に みる昆虫の体のつくりに関する内容等を補完したり, 改善したりするための学習指導の展開（昆虫のあし の数や接続部分 (胸部) に重点を置き, 胸部の三つ の体節（前・中・後胸部）の名称や, 頭部・胸部 腹部の内部構造等を取り上げる等) を提案している。 小 3 に体節や内部構造等の認識が可能か否か等の検
証や, 学習機会の拡大等 (小学校理科の複数学年で 昆虫の学習を取り上げること等）も視野に入れて, 慎重に検討を重ねる必要がある。

また，学習指導方策の試行に向けて，必要な学習 指導資料等についても性急に開発しなければならな い。合わせて，自らの課題としたい。

\section{附記}

本研究は, JSPS 科研費 17K12932, 16K04675, 17K01024 の助成を受けたものである。

\section{引用文献}

有馬朗人ほか $(2017)$ 『新編たのしい理科 3 年』大日本図書. Badders, W. et al. (2007). Houghton Mifflin Science (3th grade). Boston, U.S.A.: Houghton Mifflin Company.

Cinici, A. (2013). From caterpillar to butterfly: a window for looking into students' ideas about life cycle and life forms of insects. Journal of Biological Education, 47(2), 84-95.

Dispezio, M.A. et al. (2015). Texas Science Fusion (Grade 2). Texas, U.S.A.: Houghton Mifflin Harcourt.

日高敏隆（1989）『昆虫たちの驚異』アスク講談社.

日置光久・星野昌治 $(2007)$ 『シリーズ日本型理科教育／第 2 巻「子ども」はどう考えているか一とらえやすい自 然認識と科学概念一』東洋館出版社.

市川英貴（2009）「子どもの「見方」を変える観察一小学校 での観察の指導一」『理科の教育』第 58 卷，第 11 号, 46-49.

石塚小太郎 (2014) 『ミミズ図鑑』三松堂.

石浦章一ほか (2017)『わくわく理科 3』啓林館.

岩間淳子・松原静郎・下條隆嗣（2008）「生物多様性の観 点から見た小学校理科教科書に扔ける動物教材の扱い 一興味・関心を持たせる教科書の開発をめざして一」 『科学教育研究』第 32 巻, 第 1 号, 27-38.

岩下育男（2001）「アリを教材に生かす〜共生の生態学を理 科教育に〜」『理科の教育』第 50 巻, 第 3 号, 58-61.

海保博之編著（1986）『心理・教育デー夕の解析法 10 講 基 礎編』福村出版。

上岡学（2009）「理科教育における昆虫のからだの認識に 関する研究一大学生を対象としたアリのからだの認識 一」『日本教育心理学会第 51 回総会発表論文集』167.

癸生川武次ほか (2017)『楽しい理科 3 年』信州教育出版社.

松森靖夫（2000）『子どもの本音を知ろう! 新しい評価方法 はこれだ『自然』についての見方・考え方の調查と分 析』学校図書.

松森靖夫・菅沼美奈・佐久間理志（2013）「小学校教員志望 学生の「昆虫の体のつくり」に関する認識状態の分析 一「昆虫の体のつくり」に関する教授方策の再考一」 『山梨大学教育人間科学部紀要』第 15 巻, 223-233.

松森靖夫・佐藤寛之・望月文 (2014)「チョウの生活環と生 活様式に対する小学校教員志望学生の認識状態につい 
て一Cinici（2013）の調査問題を参考にして一」『山梨 大学教育人間科学部紀要』第 16 卷, 157-165.

文部科学省 (2017a) 『小学校学習指導要領解説理科編』東 洋館出版社.

文部科学省 (2017b) 『中学校学習指導要領解説理科編』学 校図書.

毛利衛ほか (2017) 『新編新しい理科 3 年』東京書籍.

佐々木智謙・佐藤寛之・塚原健将・松森靖夫 (2018)「「昆 虫の体のつくり」の学習前後における児童の認識状態 の評価一自由記述法と描画法を併用して一」『理科教 育学研究』第 58 巻, 第 4 号, 403-410.

Shepardson, D.P. (2002). Bugs, butterflies, and spiders: Children's understandings about insects. International Journal of Science Education, 24(6), 627-643.

柴一実 - 山崎敬人 · 岸俊之 - 中田晋介 - 真田美保 - 秋山 哲・土井徹・田原潤（2008）「小学校理科における学 び文化の創造（8）一科学館等の出前授業が子どもの昆 虫理科に及ぼす影響に関する研究一」『広島大学 学部・
附属学校共同研究機構研究紀要』第 36 号, 349-358. 霜田光一ほか（2017）『みんなと学ぶ小学校理科 3 年』学校 図書.

矢田光宏 (2005)「模型づくりを通して科学的概念の形成を はかる一こん虫のなかまをさがそう一」『理科の教育』 第 54 巻, 第 1 号, 50-52.

八木剛（2010）「昆虫リテラシー向上のための基礎資料一 展覧会「神戸元町・夏の昆虫館」における展示標本へ の人気投票から見た, 男女別, 年齢層別の昆虫の好み 一」『きべりはむし』第 32 卷, 第 2 号, 26-37.

山野井貴浩 · 大坂里奈 · 及川貴也 (2015)「昆虫の体のつく りの理解を促すとともに進化的視点から考察を行う 機会を提供する生物教材の開発〜アリとアリグモの 比較を通して〜」『科学教育研究』第 39 巻, 第 4 号, 367-379.

養老孟司ほか（2017）『みらいをひらく小学理科 3』教育出版 .

(2018 年 10 月 12 日受付, 2019 年 1 月 16 日受理) 


\title{
A Study of Fostering Elementary School Children's Knowledge and Scientific Skills in the Unit "Life": Based on Children's Recognitions of the Morphology of Insects
}

\author{
Tomonori SASAKI ${ }^{1}$, Hiroyuki SATO ${ }^{1}$, Kensho TSUKAHARA ${ }^{2}$, Yasuo MATSUMORI ${ }^{1}$ \\ ${ }^{1}$ Graduate School Department of Interdisciplinary Research, University of Yamanashi \\ ${ }^{2}$ Graduate School of Education, University of Yamanashi
}

\section{SUMMARY}

The main purpose of this study is to analyze elementary school students' recognitions of the morphology of insects as drawn from the ventral side in the 2nd grade (before learning) and the 3rd grade (after learning), and to examine the perspective to foster children's learning and skills development in science. The main findings of this study were as follows: 1 ) more than $60 \%$ of the 2nd grade students and more than $80 \%$ of the 3rd grade students could distinguish between insects and other living things (among nine kinds) ; and 2) none of the 2nd grade students and about $20 \%$ of the 3rd grade students divided morphology of six kinds of insects into three segments (head, thoracic, and abdomen) correctly, and the correct answer rates for each insect were less than $10 \%$ for the 2 nd grade students and less than $65 \%$ among the 3 rd grade students. The morphology of the six kinds of insects studied can be correctly classified into 4 types at the head, 9 types at the thoracic and 3 types at the abdomen; therefore, based on these results, we suggested that improvement in the teaching and learning strategies about the morphology of insects is necessary.

$<$ Key words $>$ morphology of insects, elementary school science, scientific recognition, biological education, knowledge and scientific skills in the unit "life" 